\title{
子豚におけるトゥモロコシー大豆粕飼料へのアミノ酸 添加効果とトレオニン要求量
}

\author{
梶 雄次・古谷 修・浅野 猛*・村山隆一* \\ 農林水産省九州農業試験場, 熊本県西合志町 861-11 \\ *日本化薬（株）総合研究所，高崎市 370-12
}

(1988. 7. 5 受付)

\begin{abstract}
要 約 子豚におけるLートリプトファン $0.05 \%$ 添加トゥモロコシー大豆粕基礎眗料へのリシン， ト レオニン,メチオニン、イソロイシンおよびバリンの添加効果ならびにトレオニンの要求量を朋らかに する目的で，不断給飼，群飼の条件下で 3 週間の発育試験を 4 回にわたって夷施した，1）実験 1 では， 体重約 $25 \mathrm{~kg}$ の子豚 24 頭を用い，基礎飼料への L-リジン塩酸塭 $0.5 \%$ （リジンとして $0.4 \%$ ， L-卜 レオニン $0.1 \%$ および DLーメチオニン $0.1 \%$ の添加効果を調べた，基脴飼料の組成はリジン $0.44 \%$, トレオニン $0.39 \%$, 含硫アミノ酸（メチオニン+シスチン） $0.49 \%$, トリプトファン $0.15 \%$ および粗 蛋白質 (CP) $10.7 \%$ であった. 3 種のアミ/酸汪合物を添加した場合には，1日增体量（DG）および 飼料要求率（FCR）はそれぞれ $762 \mathrm{~g}$ および 2.5 , 混合物からメチオニンのみを除いた場合はそれぞ

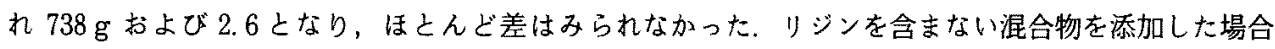
にはそれぞれ $524 \mathrm{~g}$ および 3.2 で，発育成績は著しく劣った，混合物からトレオニンを除くとそれぞ れ $619 \mathrm{~g}$ および 2.8 となり，中間的な值であった，2）奏験 2 および 3 では，いずれす体重約 $24 \mathrm{~kg} の$ 子豚を 20 頭用い，トレオニン要求量を検討した． L-リジン塩酸塩を $0.5 \%$ 添加した基礎飼料に L-卜 レオニンを，実験 2 では $0,0.05 ， 0.1$ および $0.15 \%$ ，実験 3 では $0,0.1 ， 0.15$ および $0.2 \%$ 添加し て発育の反応をみた．DG および FCR は L-トレオニンの添加量が $0.1 〜 0.15 \%$ までは直線的に変化 したが，それ以上添加しても効果はみられなかった．DG および FCR を指標とすると，トレオニン の要求量はそれぞれ飼料中含量 0.51 および $0.49 \%$ と推定された．3）実験 4 では, 体重約 $29 \mathrm{~kg}$ の子 豚 16 頭を用い，L-リジン塩酸塩 $0.5 \%$ および L-トレオニン $0.15 \%$ 添加した基礎飼料に対して L-1 ソロイシンおよび L-バリンをいずれも $0.1 \%$ 添加した場合の効果を調べたが，それらの添加効果は認 められなかった，4）以上の試験結果から，CP 10.7\%で，トリプトファンを添加したトゥモロコシー 大豆粕飼料における第 1 および第 2 の制限アミノ酸はそれぞれリジンおよびトレオニンであり，含硫了 ミノ酸、イソロイシンおよびバリンは不足しないことが示唆された。
\end{abstract}

日畜会報，59(12)：1013-1018，1988

養豚飼料ではりジンが第 1 制限アミノ酸になりやすい ため, リジンの要求量を求める研究は数多くみられるが, その他の必須了ミ/酸の要求量について些比皎的報告が 少ない。

トレオニンはリジンについで欠乏しやすいアミノ酸の 1つである，著者らは，さきに，血频中尿素窒素（PUN） を指標としてトレオニンの要求量を推定し、リジンに対 するトレオニンの比率として 57〜63\% という結果を得 だ.ここれ $\mathrm{ARC}$ 標準 ${ }^{2)}$ の提唱している比率の $60 \%$ と
ほぼ一致している。

本研究は, トゥモロコシー大豆粕飼料へのいくつかの 必須アミノ酸の添加氻果を調べるとともに, PUN を指 標として推定したトレオニン要求量 ${ }^{1}$ を子豚の発育成績 を指標とする方法で確かめることを目的に実施した。

\section{材料および方法}

低蛋白質飼料へのリジン，トレオニン㧍よびメチオニ ン添加効果（実験 1) 
平均初体重約 $25 \mathrm{~kg}$ の子豚 24 顽を用い, 6 頭ずつの 4 群に分け，3週間にわたる発育試験を実施した。豚は, コンクリート床の豚房に群飼とし，豚舎内の環境温度は $23 \pm 1^{\circ} \mathrm{C}$ に保った。

供試飼料はトゥモロコシと大豆粕を主体とする基礎鸰 料（表 1)に，L-リシン，Lートレオ二ン，DLーメチオ

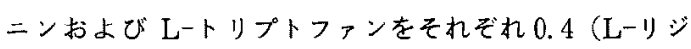
ン塩酸塩としては 0.5)，0.1，0.1 および $0.05 \%$ 添加し た全アミノ酸添加飼料，これらのアミノ酸のうち、リシ ン、トレオニンおよびメチオニンのいずれかを無添加と した 3 種の飼料の合計 4 種類を用い，これらを 4 群の子 豚のいずれかに無作為に割り当てて給与した。なお，飼 料の粗蛋白質 (CP) 含量が全飼料で一定となるように カゼインで調整したが，これは夷験 2〜4でも同様であ った。また、リジンの飼料中含量は，著者らがさきに 1 日堌体量を指標として推定した体重 $20 \sim 35 \mathrm{~kg}$ の子豚

Table 1. Composition of the basal diet used in the present study

\begin{tabular}{lr}
\hline \hline Ingredient (\%) & \\
Yellow corn & 87.0 \\
Soybean meal & 10.0 \\
Tricalcium carbonate & 0.8 \\
Calcium carbonate & 1.2 \\
Sodium chloride & 0.5 \\
Vitamin and mineral mixture* & 0.5 \\
Chemical composition(by analysis) & \\
Dry matter, \%6 & 87.2 \\
Crude protein,\% & 10.7 \\
Gross energy, cal/g & 3810 \\
Digestible energy, cal/g & 3130 \\
Amino acid composition(by analysis, $\%$ ) \\
Arginine & 0.63 \\
Histidine & 0.27 \\
Isoleucine & 0.44 \\
Leucine & 1.08 \\
Lysine & 0.44 \\
Methionine & 0.25 \\
Cystine & 0.24 \\
Phenylalanine & 0.51 \\
Tyrosine & 0.42 \\
Threonine & 0.39 \\
Tryptophan & 0.10 \\
Valine & 0.54 \\
\hline
\end{tabular}

*See Kaji and Furuya"
のリジン要求量 $0.84 \%$ を満たすように設定した.

トレネニン要求量の検討（実験 2 および 3 ）

実験 2 および3のいずれにおいてす，平均初体重約 $24 \mathrm{~kg}$ の子豚 20 頭を 5 頭ずつの 4 群に分け, 実験 1 と 同じ基礎飼料に L-リジンおよび L-トリプトファンを それぞれ 0.4 および $0.05 \%$ 添加し，実験 2 では，L一卜 レオニンを $0,0.05 ， 0.1$ あるいは $0.15 \%$ 添加した 4 種 類，また，実験 3 では，Lートレオ二ンを $0,0.1 ， 0.15$ あるいは $0.20 \%$ 添加した 4 種類の飼料を給与した. そ の他の実験条件は実験 1 上同様であった．

実験 3 では，さらに，基礎飼料の可消化エネルギー （DE）を求めるために消化試験を実施した．すなわち， 試験最後の 3 週目に, 飼料に酸化ク口ムを $0.1 \%$ 混合し て給与し，酸化クロム指標物質法》によって総エネルギ 一の消化率を算出した，基礎飼料の $\mathrm{DE}$ は，添加した アミノ酸およびカゼインの総エネルギーの消化率は 100 $\%$ と仮定して求めた。

イソロインンおよびバリンの添加効果（実験 4)

本試験の基礎飼料に用いたトゥモロコシの CP 含量 は $7.19 \%$ 上飼料成分表 ${ }^{5}$ の $8.8 \%$ に比較してかなり低 く，そのため，基礎飼料中の各アミ/酸含量の実測值は 計算値に比べ低かった，とくに，イソロイシンの基整飼 料中の含量は $0.44 \%$ と低く，これは日本飼養標準（1975 年版 $)^{6)}$ のインロイシンの要求量 $0.50 \%$ を満たしていな かった。またバリンについては基礎鸼料中に0. $54 \%$ で，同飼養標準の要求量 $0.50 \%$ よも多いが，場合に よっては欠乏する可能性が考えられた，そこで，実験 4 では，基礎飼料に L-リジン，L-トレオニンおよび $\mathrm{L}^{-}$ トリプトファンをそれぞれ $0.4 ， 0.15$ および $0.05 \%$ 添 加した上で，さらに L-インロイシン㧍よび $\mathrm{L}^{-ハ ゙ リ ン ~}$ をいずれも $0.1 \%$ 添加した場合の効果を調べた．平均初 体重約 $29 \mathrm{~kg}$ の子豚 16 頭を 8 頭ずつの 2 群に分け， Lイソロイシンおよび $\mathrm{L}^{-}$バリン添加飼料および無添加飼 料を給与した。なお, 飼料中 CP 含量の調整のため, 無添加飼料にはカゼインを0.2\%添加したが，これによ り飼料中のバリン含量は $0.55 \%$ に高まった. イソロイ シン含量は $0.44 \%$ で変わらなかった，その他の奏験条 件は実験 1と同様であった。

\section{化学分析および統計处理}

飼料の水分拉よび CP の分析は $\mathrm{AOAC}$ 法に準拠し た方法），エネルギーの測定はボンブ自動熱量計（島津 製作所， CA-3 型)，酸化クロムの定量はリン酸カリウ ムを用いる吉田らの方法"文によって行なった. アミノ酸 の定量は高速液体クロマトグラフ（日本ウォーターズ） を使用し，オルトフタルアルデヒド発蛍光法によったが， 
飼料は $6 \mathrm{~N}$ 程酸で $110^{\circ} \mathrm{C}, 24$ 時間の加水分解をして分 析試料とした。アミノ酸のうち，トリプトファンは生雲 らの方法”，また，シスチンは SPENCER and WOLD の 方法 ${ }^{8)}$ で分析したが，プロリンは測定しなかった，好理 区間の有意性の㭘定は TUKEY の方法”で行なった。

\section{結果および考察}

実験 1 では，基礎飼料に L-トリプトファンを $0.05 \%$ 添加した飼料に，養豚飼料で久そしやすいとされるリジ ン、トレオニンおよびメチオニンを添加してその效果を 調べた，その結果を表 2 に示したが，それによると，1 日增体量 (DG)，1日飼料摄取量（FI），および飼料要 求率（FCR）のいずれにおいても，リジン無添加区が 著しく劣り，DGにおいては，全アミノ酸添加区㧍よ びメチォニン無添加区との間に有意差 $(\mathrm{P}<0.05)$ が認 められた。 ついでトレオニン無添加区が劣っており， DGではリジン無添加区の場合と同倳に, 全アミノ酸 添加区およびメチオニン無添加区との間に有意差（P く0.05）か諗められた. 一方，メチオニン然添加区では, $\mathrm{DG}, \mathrm{FI}$ およ゙ $\mathrm{FCR}$ のいず机においても全アミノ酸 添加区とほとんど差がみられなかった。

これらの結果から，トウモロコシおよび大豆粕を主体 としたトリプトファン0.05\% 添加の低蛋白質飼料では， まず，リジンが欠そし，その要求量を満たすように゙リ ジンを添加した場合には，トレオニンが欠そすることが 示された.メチオニン（含硫アミノ酸）はほぼ要求量を
満足しているものよ判断された，基礎飼料中の含硫ア ノ酸（メチォニントシスチン）含量は $0.49 \%$ であった (表 1) が，この值は，日本飼養標準 $(1975 \text { 年版 })^{6)}$ に求 ける要求量 $0.54 \%$ (体重 $20 \sim 35 \mathrm{~kg}$ ) より6低く, 最 近刊行された日本飼養標準 (1987 年版 $)^{109}$ の0.43\%よ りも多い， $\mathrm{ARC}^{2)}$ によると，リジンに対する含硫アミ ，酸の割合は $50 \%$ が理想的としているが，本実験での Lーリジン添加飼料のリジン含量 $0.84 \%$ かすすれば含硫 アミノ酸は $0.42 \%$ でよいことになる，NRC 標準(1988 年版 ${ }^{11)}$ によると，体重 $20 \sim 50 \mathrm{~kg}$ の子豚の含硫了ミ， 酸要求量は $0.41 \%$ 上かなり低い，本奏験の結果お上び 最近改訂された飼養標染 ${ }^{2}$ 10,11) 加らすれば，旧版の日本 飼養標準 ${ }^{6}$ の含硫了ミ/酸要求量の $0.54 \%$ は高すぎた と考えられる。

奏験 2 および 3 においては，実験 1 で基礎飼料中のト レオニン含量が $0.39 \%$ では欠そすることが明らかにな ったため，Lートレォニンの添加量を変えて発育に対す

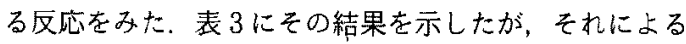
と，DGは飼料中のトレオニン含量が $0.54 \%$ までは増 加し，0.59\%ではむしろ低下した，また，FCR はトレ オニン含量が $0.49 \%$ でほほ定となった. DGおぬひ FCR について，各トレオニン添加水準毎にトレオニン 無添加の場合を 100 とする相対值で示したのが図 1 であ

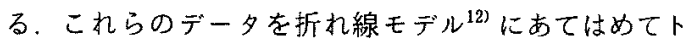
レオニン要求量を推定すると, DG および FCR から, それぞれ0.51\%および $0.49 \%$ よなった。

Table 2. Amount of amino acids added to the basal diet and growth response of pigs in experiment 1

\begin{tabular}{|c|c|c|c|c|c|}
\hline & \multicolumn{4}{|c|}{ Diet } & \multirow[b]{3}{*}{$\mathrm{SE}^{*}$} \\
\hline & \multirow[b]{2}{*}{$\begin{array}{l}\text { Supplemented with } \\
\text { all the amino acids }\end{array}$} & \multicolumn{3}{|c|}{ Lacking amino acid in mixture } & \\
\hline & & Lysine & Threonine & Methionine & \\
\hline \multicolumn{6}{|c|}{ Added amino acids and casein, $\%$} \\
\hline L-lysine & $0.4(0.84)^{* *}$ & $-(0.47)$ & $0.4(0.85)$ & $0.4(0.85)$ & \\
\hline L-threonine & $0.1(0.49)$ & $0.1(0.52)$ & $-(0.39)$ & $0.1(0.49)$ & \\
\hline DL-methionine & $0.1(0.35)$ & $0.1(0.36)$ & $0.1(0.35)$ & $-(0.25)$ & \\
\hline $\mathrm{L}$-tryptophan & $0.05(0.15)$ & $0.05(0.15)$ & $0.05(0.15)$ & $0.05(0.15)$ & \\
\hline Casein & - & 0.5 & 0.1 & 0.1 & \\
\hline Daily gain, $\mathrm{g}$ & $762^{\mathrm{a}}$ & $524^{\mathrm{b}}$ & $619^{b}$ & $738^{\mathbf{a}}$ & 28 \\
\hline Daily feed intake, $\mathrm{g}$ & 1882 & 1659 & 1740 & 1895 & \\
\hline Feed conversion ratio & 2.5 & 3.2 & 2.8 & 2.6 & \\
\hline
\end{tabular}

* Standard error of the mean for six pigs.

** The number in parenthesis indicates the total amino acid content.

a, $b$ Means for the daily gain with different superscripts differ $(P<0.05)$. 
Table 3. Effect of amount of threonine added to the basal diet supplemented with L-lysine $0.4 \%$ and L-tryptophan $0.05 \%$ on the growth response of pigs in experiments 2 and 3

\begin{tabular}{lcccccc}
\hline \hline & \multicolumn{5}{c}{ Threonine level in $\operatorname{diet}(\%)$} & \\
\cline { 2 - 6 } & 0.39 & 0.44 & 0.49 & 0.54 & 0.59 & $\mathrm{SE}^{*}$ \\
\hline Experiment 2 & $608^{\mathrm{a}}$ & $661^{\mathrm{ab}}$ & $719^{\mathrm{ab}}$ & $779^{\mathrm{b}}$ & - & 41 \\
Daily gain, g & 1654 & 1697 & 1785 & 1922 & - & \\
Daily feed intake, g & 2.7 & 2.6 & 2.5 & 2.5 & - & \\
$\quad$ Feed conversion ratio & & & & & & \\
Experiment 3 & 564 & - & 703 & 719 & 690 & 66 \\
Daily gain, g & 1519 & - & 1594 & 1693 & 1576 & \\
Daily feed intake, g & 2.7 & - & 2.3 & 2.4 & 2.3 & \\
Feed conversion ratio & & & & & \\
\hline
\end{tabular}

* Standard error of the mean for five pigs.

${ }^{a, b}$ Means for the daily gain with different superscripts differ $(P<0.05)$.

Table 4. Effect of added L-isoleucine $0.1 \%$ and $\mathrm{L}$-valine $0.1 \%$ to the basal diet supplemented with L-lysine $0.4 \%$, L-threonine $0.15 \%$ and $\mathrm{L}-$ tryptophan $0.05 \%$ on the growth response of pigs in experiment 4

\begin{tabular}{|c|c|c|c|}
\hline & \multicolumn{2}{|c|}{ Diet } & \multirow[b]{2}{*}{$\mathrm{SE}^{*}$} \\
\hline & \multicolumn{2}{|c|}{ Addition No addition } & \\
\hline Daily gain, g & 746 & 760 & 35 \\
\hline Daily feed intake, $\mathrm{g}$ & g $\quad 2037$ & 2070 & \\
\hline Feed conversion rati & tio 2.7 & 2.7 & \\
\hline
\end{tabular}

* Standard error of the mean for eight pigs.

トレオニンの要求量は旧版の日本飼養標準 ${ }^{6}$ および $\mathrm{NRC}^{13)}$ では，いずれにおいてす $0.45 \%$ (体重 20 35 $\mathrm{kg}$ ）で，本奏験で得られた值よりあ低かった，しかし ながら，新版ではそれぞれ $0.51 \%$ (体重 $20 \sim 35 \mathrm{~kg})^{10)}$ および $0.48 \%$ (体重 $20 \sim 50 \mathrm{~kg})^{\mathrm{M})}$ しなってお゙り，本実 験結果と一致している.さらに，ARC $\mathrm{AR}^{22}$ でトレオニ ンのリジンに対する比率を $60 \%$ ししているが，これに よるとリジンが $0.84 \%$ の場合にはトレオニンの要求量 は $0.50 \%$ となり，本実験結果とよく一致した。

奏験 4 では，リジン，トレオニンおよびトリプトファ ンをそれらの要求量を満たすように基礎飼料に添加した 上で，さらにイソロイシン拈よびバリンを加えてその効 果をみた，結果を表 4 に示したが，それによると，DG， FI および FCR とあまったく差は認められなかった。

このことは，基礎飼料にカゼインを $0.2 \%$ 添加した場合 のイソロイシンおよびバリンの含量, それぞれ，0.44\% および $0.55 \%$ でそれらの要求罣が満足されていたこと を示唆している。

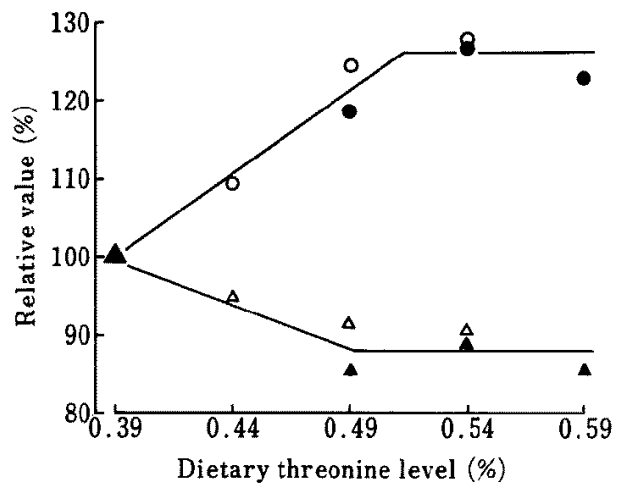

Fig. 1. Effects of threonine level in diet on daily gain $(O$ for experiment 2 and for experiment 3 ) and feed conversion ratio $(\triangle$ for experiment 2 and $\boldsymbol{\Delta}$ for experiment 3 ). Each point represents the relative value compared with daily gain or feed conversion ratio for the basal diet containing $0.39 \%$ threonine.

イソロイシンの要求量は，わが国の飼養標準 ${ }^{10)}$ お び NRC ${ }^{11)}$ の新版ではそれぞれ，0.47および $0.46 \%$ と， いずれす旧版よりも低く森っており，本実験で供試した 飼料のイソロイシン含量の $0.44 \%$ は要求量をほぼ満足 していたものと考えられる。

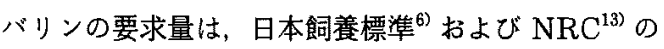
旧版ではいずれあ $0.50 \%$ であったが，新版をみると， 日本飼養標準 ${ }^{103}$ が $0.59 \%$ と高まったのに対し， $\mathrm{NRC}^{11}$ では，体重区分が $20 \sim 35 \mathrm{~kg}$ から 20〜50 kg になったことああると考えられるが，0.48\%と低くな り，両飼盖標準には約 $0.1 \%$ の差が生じた，実験 4 では 
バリン含量を $0.55 \%$ から $0.64 \%$ に高めたが，発育には 添加効果が認められず，このことから，日本飼養標準 $(1987)^{103}$ のバリンの要求量 $0.59 \%$ はやや高すぎる可能 性がある，わか国の飼養標準におけるアミノ酸要求量は, リジン以外については， $\mathrm{ARC}^{2)}$ が推貁するアミノ酸パ ターンに基づいてリジンとの比率から算出しており, バ リンはリジンの $70 \%$ とている ${ }^{10)}$ ここの点, NRC $(1988 \text { 年版 })^{11)}$ では, バリンのリジンに対する比率を 64 \%とやや低くみている。この比率に基づくと、リジン 含量が $0.84 \%$ の場合のバリンの要求量は $0.54 \%$ で, 本 実験で供試した基礎飼料のバリン含量に等しい。

RusseLL らは，CP 11\% のトゥモロコシー大豆粕飼料 でバリンの要求量を検討し，基礎飼料中に含まれたバリ ン含量 $0.51 \%$ では最高の DG が得られなかったと報告 している ${ }^{14)}$. したがって，本実験においてす，バリンの 要求量は満たされていたもののぎりぎりの限界にあった あのと判断される。

著者らはPUN を指標とし，実用養豚飼料でリジン についで欠乏しやすいとされるトレオニン，含硫了ミ， 酸, トリプトファン, イソロイシンおよびバリンの要求 量について検討している゙，その結果，トレオニンの要 求量は飼料中含量 $0.47 \sim 0.57 \%$, また, 含硫了ミノ酸, イソロイシンおよびバリンの要求量は，基礎飼料に含ま れていたそれぞれの含量，すなわち，0.47，0.50およ び $0.62 \%$ で満たされていることを明らかにした。これ らの結果は，いずれも本実験の発育試験で得られた結果 と矛盾しない。

トリプトファンの要求量については本実験では検討し なかったが, 著者らはPUN を指標として, 飼料中含 量 $0.10 \sim 0.15 \%$ と推定している ${ }^{1}$. 日本飼養標準 ${ }^{102}$ お よび NRC ${ }^{11}$ はいずれも0.12\%としており，また， $\mathrm{ARC}^{2)}$ のアミノ酸パターンにおけるリジンとトリプト ファンの比率からも $0.12 \%$ と算出され，いずれむよく 一致している. したがって，本実験で供試した基礎飼料 中のトリプトファン含量 $0.1 \%$ （表 1) では不足してい たと考えられる.

本実験および既報の結果”，ならびに最近改訂された 飼養標準 ${ }^{10,11)}$ におけるアミ/酸要求量加らすれば, ト ウモロコシー大豆粕飼料に招いては，リジンについでト レオニン，トリプトフフンが次そするか，含硫アミ，酸
およびインロイシンの要求量は，CP を本実験で用いた 基礎鸰料の $10.7 \%$ 程度に低めて毛満足されるもの之判 断される、バリンについては，本実験の結果书よび $\mathrm{NRC}^{11)}$ の值からすれば要求量を満足していたもの上考 えられるが，日本飼養標準 ${ }^{10)}$ によると不足しており， また，RUSSELL ら ${ }^{14)}$ はバリンが第 4 制限アミノ酸にな る可能性を示唆しており，バリンの要求量についてはさ らに検討が必要であるう。

終わりに本稿の校閱を睗った当場八木满寿雄畜産部長, 動物管理を担当された志柿良一, 林 房高, 橋本邦博, 江藤浩幸，島崎二朗の各技官に厚くふる礼申し上げます，

\section{文献}

1）楃 雄次 - 古谷 修, 日畜会報, $58: 743-749$. 1987.

2) ARC, The Nutrient Requirements of Pigs, Commonwealth Agricultural Bureaux. 1981.

3）棍 雄次・古谷 修, 日畜会報, 58: 574-582. 1987.

4）森本 宏 (監修)，動物栄養試験法. 蒦賢堂. 東 京. 1971.

5）農林水産技術会議事務局，日本標準鸰料成分表. 中央畜産会. 東京. 1987.

6）農林水産汥術会議事務局，日本飼養慗準，豚，中 央畜産会，東京. 1975 .

7）生雲晴久・滝川明宏・亀岡暄一，日畜会報，54： 788-793. 1983.

8) SPENCER, R.L. and F. WOLD, Analyt. Biochem., 32 : 185-190. 1969.

9）吉田 実，畜産を中心とする実験計画法，101116. 養賢堂. 東京. 1971.

10）農林水産技術会議事務局，日本飼養標準，豚、中 央畜産会. 東京. 1987 .

11) NRC, Nutrient Requirements of Swine, 9th rev. ed. NAS. 1988.

12）大塚䔨雄・吉田雅彦，応用統計学，5:29-39. 1976.

13) NRC, Nutrient Requirements of Swine, 8th rev. ed, NAS. 1979.

14) Russell, L.E., B.J. KerR and R.A. EASTER, J. Anim. Sci., 65 : 1266-1272. 1987. 


\title{
The Effects of Amino Acid Supplementation of a Corn-Soybean Meal Diet and the Threonine Requirement for Growing Pigs
}

\author{
Yuji KaJi, Shu Furuya, Takeshi Asano* and \\ Takaichi MURAYAMA* \\ Kyushu National Agricultural Experiment Station, \\ Nishigoshi, Kumamoto-ken 861-11 \\ ${ }^{*}$ Nippon Kayaku Co., Ltd., Takasaki 370-12
}

Four experiments were conducted 1) to measure the response of lysine, threonine, methionine, isoleucine and valine supplementation of a L-tryptophan $0.05 \%$ supplemented corn-soybean meal basal diet, and 2) to estimate the threonine requirement for growing pigs kept under practical ad libitum group-feeding conditions. Daily gain (DG) and feed conversion ratio (FCR) were used as response criteria. 1) Experiment 1, involving 24 pigs weighing approximately $25 \mathrm{~kg}$, measured growth response to the addition of $\mathrm{L}$ lysine $\mathrm{HCl} 0.5 \%$ ( $0.4 \%$ free base), L-threonine $0.1 \%$ and DL-methionine $0.1 \%$ to the basal diet, which contained lysine $0.44 \%$, threonine $0.39 \%$, sulfur amino acids (methionine + cystine) $0.49 \%$, tryptophan $0.15 \%$ and crude protein (CP) $10.7 \%$. DG and FCR were $762 \mathrm{~g}$ and 2.5 , respectively, when the mixture of three amino acids was added, while DG was decreased to $524 \mathrm{~g}$ and FCR increased to 3.2 by adding mixture devoid of lysine. A mixture lacking methionine drew no response, $738 \mathrm{~g}$ and 2.6 , respectively-while a mixture without threonine was intermediate, $619 \mathrm{~g}$ and 2.8 , respectively. 2) In experiments 2 and 3 , we determined the threonine requirement for 20 pigs weighing approximately $24 \mathrm{~kg}$ each. We measured growth response to the addition of L-threonine, $0,0.05,0.1$ and $0.15 \%$ for experiment 2 and $0,0.1,0.15$ and $0.2 \%$ for experiment 3 , to the basal diet supplemented with L-lysine $\mathrm{HCl} 0.5 \%$. DG and FCR changed linearly as the addition of L-threonine was increased to $0.1-0.15 \%$. Further increases in the addition of L-threonine had no effect. Using DG and FCR as the response criteria, the calculated requirements for threonine were $0.51 \%$ and $0.49 \%$, respectively. 3) In experiment 4 , involving 16 pigs weighing approximately $29 \mathrm{~kg}$, we measured growth response to the addition of $\mathrm{L}$-isoleucine $0.1 \%$ and $\mathrm{L}$-valine $0.1 \%$ to the $\mathrm{L}$-lysine $\mathrm{HCl} 0.5 \%$ and $\mathrm{L}$ threonine $0.15 \%$ supplemented basal diet, which contained isoleucine $0.44 \%$ and valine $0.54 \%$. There was no response to the addition of isoleucine and valine. 4) The results of these experiments suggest that lysine and threonine are the first- and second limiting amino acids in a $10.7 \% \mathrm{CP}$, tryptophan supplemented corn-soybean meal diet, which is not limitied in sulfur amino acids, isoleucine and valine.

Jpn. J. Zootech. Sci., 59 (12) : 1013-1018, 1988

Key words : pigs, amino acid, threonine, requirement 